\title{
PENINGKATAN PEMAHAMAN KONSEP PENCEMARAN LINGKUNGAN MELALUI PENERAPAN MODEL DISCOVERY LEARNING
}

\author{
Mutiara Novianjani ${ }^{1 *}$, Bhakti Karyadi ${ }^{1}$, dan Irdam Idrus ${ }^{1}$ \\ ${ }^{1}$ Program Studi Pendidikan Biologi, Fakultas Keguruan dan Ilmu Pendidikan, Universitas Bengkulu \\ Email : novianjanimutiara01@gmail.com
}

\begin{abstract}
Abstrak
Penelitian ini bertujuan untuk meningkatkan aktivitas dan pemahaman konsep peserta didik kelas $\mathrm{VII}_{4}$ SMPN 4 Kota Bengkulu melalui model pembelajaran discovery learning. Jenis penelitian ini termasuk dalam penelitian tindakan kelas dengan metode deskriptif. Penelitian ini terdiri dari dua siklus, setiap siklus terdiri dari empat tahap, yaitu: perencanaan, pelaksanaan, observasi, refleksi. Subyek penelitian adalah peneliti sebagai guru dan peserta didik kelas $\mathrm{VII}_{4} \mathrm{SMPN} 4$ Kota Bengkulu pada tahun ajaran 2018/2019 yang berjumlah 33 orang. Variabel penelitian ini adalah pemahaman konsep peserta didik dan modelpembelajaran discovery learning. Instrumen yang digunakan berupa lembar observasi aktivitas guru dan lembar tes pemahaman konsep peserta didik. Teknik analisis data yang digunakan yaitu deksriptif yang menggambarkan hasil observasi dan tes. Hasil penelitian menunjukkan bahwa rerata aktivitas guru pada siklus I sebesar 23 (baik) dan pada siklus II meningkat menjadi 25 (baik). Rata-rata pemahaman konsep peserta didik pada siklus I yaitu 74,7 (baik) meningkat menjadi 82,8 (sangat baik). Kesimpulan dari penelitian ini adalah penerapan model pembelajaran Discovery Learning dapat meningkatkan aktivitas dan pemahaman konsep pencemaran lingkungan peserta didik kelas $\mathrm{VII}_{4} \mathrm{SMPN} 4$ Kota Bengkulu.
\end{abstract}

Kata kunci: Discovery Learning, Pemahaman Konsep, pencemaran lingkungan

\begin{abstract}
This study aims to improve the activity and understanding of the concept of class $\mathrm{VII}_{4}$ students of SMP 4 Bengkulu City through discovery learning models. This type of research is included in classroom action research with descriptive methods. This study consists of two cycles, each cycle consisting of four stages, namely: planning, implementation, observation, reflection. The research subjects were researchers as teachers and students of class $\mathrm{VII}_{4}$ of SMP 4 Kota Bengkulu in the 2018/2019 school year, which totaled 33 people. The variable of this research is understanding the concepts of students and discovery learning models. The instruments used were in the form of observation sheets for the activities of teachers and a test sheet for understanding the concepts of students. Data analysis techniques used were the mean and score categories. The results showed that the average activity of teachers in the first cycle was 23 (good) and in the second cycle increased to 25 (good). The average conceptual understanding of students in the first cycle was 74.9 (good), increasing to 82.8 (very good). The conclusion of this study is the application of the Discovery Learning model can improve the activity and understanding of the concept of environmental pollution of students of class VII4 of SMP 4 Bengkulu City.
\end{abstract}

Keywords: Discovery Learning, understanding of concept, environmental pollution 


\section{PENDAHULUAN}

Pemahaman konsep dalam pembelajaran IPA merupakan hal yang sangat penting dalam suatu pembelajaran. Berdasarkan data survei Trends International Mathematics and Science Study (TIMSS) yang dikoordinasikan oleh International Association for the Evolution of Education Achievement (IEA) pada tahun 2015 dengan objek yang diuji peserta didik SD dan SMP, Indonesia menempati urutan ke-45 dari 48 negara dengan skor 397. Secara umum kemampuan sains peserta didik di Indonesia berada pada tahapan terendah (Low International Brenchmark) karena masih dibawah nilai rata-rata (500) TIMSS (Kemendikbud, 2016). Penilaian yang dilakukan oleh tim survei TIMSS adalah kemampuan pemecahan masalah peserta didik pada mata pelajaran matematika dan sains. Hasil penilaian awal oleh peneliti mengungkapkan bahwa peserta didik belum mampu memecahkan masalah dikarenakan kurangnya pemahaman konsep dari materi yang diajarkan.

Rendahnya kemampuan peserta didik dalam memahami konsep ini antara lain disebabkan oleh proses pembelajaran yang terpusat guru, serta peserta didik cenderung pasif dalam membangun pengetahuannya sehingga konsep dari suatu materi kurang dapat dipahami oleh peserta didik.

Hasil observasi awal dan wawancara dengan guru IPA kelas $\mathrm{VII}_{4}$ SMPN 04 Kota Bengkulu pada saat magang 1 dan magang 2 tahun ajaran 2017/2018, diperoleh informasi bahwa pemahaman konsep peserta didik pada materi pencemaran lingkungan belum mencapai ketuntasan klasikal yang telah ditentukan ( $\geq 85 \%$ ) di SMPN 04 kota Bengkulu. Sedangkan persentase klasikal yang diperoleh peserta didik yaitu $70 \%$.
Rendahnya persentase ketuntasan klasikal tersebut diduga berkaitan dengan proses pembelajaran pada kelas $\mathrm{VII}_{4} \mathrm{SMPN}$ 04 Kota Bengkulu. Metode yang dominan diterapkan yaitu metode ceramah. Keadaan tersebut menyebabkan masih banyaknya siswa yang belum menguasai konsep. Pemilihan model pembelajaran yang memfasilitasi peserta didik melakukan aktifitas sainstifik perlu dilakukan.

Salah satu model pembelajaran yang memiliki pendekatan sainstifik yaitu discovery learning. Menurut Bruner, discovery learning adalah metode belajar yang mendorong peserta didik untuk mengajukan pertanyaan dan menarik kesimpulan dari prinsip-prinsip umum praktis contoh pengalaman (Roestiyah dan Suharto, 1985).

Dari beberapa kelebihan model pembelajaran discovery learning ini diharapkan dapat meningkatkan pemahaman konsep peserta didik karena dengan model pembelajaran tersebut menuntut peserta didik untuk menemukan sendiri konsep yang terdapat dalam materi yang diajarkan sehingga konsep yang diterima akan lebih melekat dalam ingatan peserta didik. Materi ajar yang akan diperbaiki pada penelitian ini adalah materi Pencemaran Lingkungan dengan Kompetensi Dasar 3.8 yaitu menganalisis terjadinya pencemaran lingkungan dan dampaknya bagi ekosistem.

\section{METODE}

Penelitian ini merupakan Penelitian Tindakan Kelas (PTK) dengan metode deskriptif yang dilakukan dalam 2 kali siklus, setiap siklus terdiri tahap perencanaan, pelaksanaan, pengamatan dan refleksi. Penelitian dilaksanakan pada semester genap tahun ajaran 2018/2019 di SMPN 04 Kota Bengkulu. Peneliti sebagai guru dibantu oleh 2 orang observer dalam 
mengobservasi aktivitas guru dalam kegiatan pembelajaran dengan model Discovery Learning. Subjek penelitian yaitu peserta didik kelas $\mathrm{VII}_{4}$ berjumlah 33 orang yang terdiri dari 13 peserta didik laki-laki dan 20 perempuan.

Teknik pengumpulan data dalam penelitian ini adalah observasi dan tes. Instrumen yang digunakan berupa lembar observasi aktivitas guru dan lembar tes. Lembar observasi aktivitas guru digunakan untuk mengobservasi aktivitas guru dalam kegiatan pembelajaran dengan model Discovery Learning. Lembar tes terdiri dari soal-soal essay yang digunakan untuk mengukur pemahaman konsep pada tiap level pemahaman.

Data hasil observasi aktivitas guru dianalisis dengan rerata skor dan kategori rerata skor. Kategori rerata skor aktivitas guru terdiri dari 3 kategori, yaitu Baik, Cukup, dan Kurang. Kisaran skor untuk tiap kategori ditentukan dengan rumus berikut.

$$
\text { Rata-rata skor }=\frac{\text { jumlah skor }}{\text { jumlah pengamat }}
$$

(Sudijono, 2014)

Kategori aktivitas mengajar guru dapat dilihat padaTabel 1.

Tabel 1. Kategori Nilai Lembar Observasi Aktivitas Guru

\begin{tabular}{cc}
\hline Rentang Skor & Kategori Penilaian \\
\hline $9-15$ & Kurang \\
$16-22$ & Cukup \\
$23-29$ & Baik \\
& \\
\hline
\end{tabular}

Data kemampuan pemahaman konsep peserta didik pada kedua siklus dianalisis dengan rerata, kategori rerata dan persentase ketuntasan klasikal peserta didik. Rerata nilai pemahaman dapat dihitung menggunakan rumus:

$$
\text { Rerata Nilai }=\frac{\sum X}{N}
$$

Keterangan rumus:

$\Sigma X$ : jumlah nilai kemampuan pemahaman konsep

$\mathrm{N}$ : jumlah peserta didik

Kategori pemahaman konsep peserta didik dapat dilihat pada Tabel 2.

Tabel 2. Kategori nilai pemahaman konsep

\begin{tabular}{cl}
\hline Rentang Skor & Kategori Penilaian \\
\hline $0-20$ & Sangat Kurang \\
$21-40$ & Kurang \\
$41-60$ & Cukup \\
$61-80$ & Baik \\
$81-100$ & Sangat Baik
\end{tabular}

Sedangkan persentase ketuntasan klasikal pemahaman konsep peserta didik dihitung dengan menggunakan rumus:

Keterangan rumus:

$$
P=\frac{\sum X}{N} X 100 \%
$$

$P$ : Persentase ketuntasan pemahaman konsep peserta didik

$\Sigma x$ : Jumlah peserta didik yang berada di bawah/di atas KKM

$\mathrm{N}$ : Jumlah seluruh peserta didik

\section{HASIL DAN PEMBAHASAN}

Berdasarkan penelitian yang telah dilakukan rata-rata skor hasil observasi aktivitas guru dalam kegiatan pembelajaran dengan model discovery learning dapat dilihat pada Gambar 1.

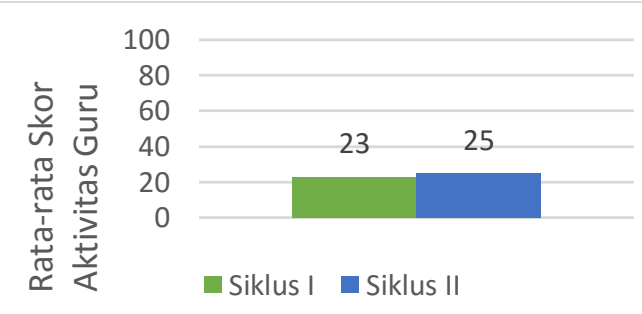

Gambar 1. Rata-Rata Skor Aktivitas Guru dengan Menerapkan Model discovery learning.

Sedangkan hasil rata-rata pemahaman konsep peserta didik pada siklus I dan Siklus II melalui penerapan model pembelajaran discovery learning 
pada materi pencemaran lingkungan dapat dilihat pada Gambar 2.

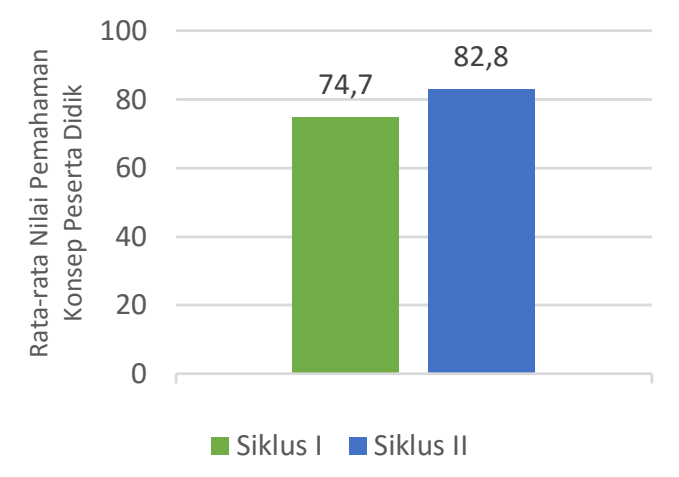

Gambar 2. Rata-rata nilai Pemahaman Konsep Peserta Didik

Pada aktivitas guru dan pada siklus I dan siklus || sudah tergolong ke dalam kriteria baik. Pada tahap stimulasi terdapat masing-masing 2 kegiatan yaitu memotivasi peserta didik dengan menampilkan video dan menyampaikan tujuan pembelajaran. Pada aspek pertama yaitu memotivasi dengan memberikan video pencemaran air di siklus I dan pencemaran tanah di siklus II. Pada siklus I dan II guru telah optimal dalam aspek tujuan pembelajaran. Pada siklus I, guru menampilkan video yang sesuai dengan sub materi yang dipelajari yaitu pencemaran air yaitu berupa gambaran tentang pencemaran air yang banyak terjadi di kehidupan sehari-hari serta contoh kegiatan apa saja yang dapat menyebabkan pencemaran pada air dan dampaknya terhadap lingkungan. Sedangkan pada siklus II, Guru menampilkan video yang sesuai dengan sub materi pencemaran tanah yaitu berupa gambaran tentang pencemaran tanah yang banyak terjadi di kehidupan sehari-hari.

$$
\text { Pada aspek kedua yaitu }
$$
menyampaikan tujuan pembelajaran. Tujuan pembelajaran merupakan kegiatan yang wajib untuk disampaikan terhadap peserta didik. Dalam menyampaikan tujuan sebaiknya guru menuliskan tujuan pembelajaran tersebut di papan tulis agar peserta didik lebih termotivasi untuk mengetahui hal apa saja yang harus di dapatkan pada proses pembelajaran. Pada siklus I dan II guru telah optimal dalam aspek tujuan pembelajaran. Guru telah menuliskan dan menjelaskan poin demi poin yang akan dicapai pada proses pembelajaran sesuai dengan materi dan percobaan pencemaran air tentang pengaruh konsentrasi detergen terhadap kelangsungan hidup ikan. Begitupula pada siklus II, guru menuliskan dan menjelaskan tujuan pelajaran yang sesuai dengan sub materi yang akan dipelajari yaitu pencemaran tanah dan sesuai dengan percobaan pengaruh konsentrasi oli terhadap kelangsungan hidup cacing tanah yang akan dilakukan.

Secara umum pada tahapan stimulasi, kedua observer menyatakan bahwa proses pembelajaran pada tahap ini telah berlangsung baik pada siklus I dan dipertahankan pada siklus II. Pemberian rangsangan atau stimulus pada awal pembelajaran adalah hal yang sangat penting dan harus dilakukan oleh guru. Tahap stimulasi penting dilakukan karena berfungsi untuk menyediakan kondisi interaksi belajar yang dapat mengembangkan dan membantu peserta didik dalam mengeksplorasi serta meningkatkan rasa ingin tahu yang tinggi. Rasa ingin tahu inilah nanti yang memotivasi peserta didik untuk terus mengikuti pembelajaran hingga mendapatkan jawaban yang jelas atas pertanyaan yang telah dibuat bersamasama dari kegiatan percobaan (Syah, 2005)

Pada tahap kedua yaitu Problem statement (pernyataan/identifikasi masalah). Berdasarkan hasil observasi, aktivitas guru dalam aspek pernyataan/identifikasi masalah pada sikus I dan II belum terlaksana secara optimal sehingga didapatkan hasil observasi 
berkategori cukup. Hal ini dikarenakan pada siklus I guru tidak mampu mengarahkan seluruh kelompok melainkan hanya 6 dari 8 kelompok yang diarahkan untuk dapat mengidentifikasi maslah sesuai dengan fenomena yang ditampilkan pada video pembelajaran tentang pencemaran air. Sehingga tidak seluruh kelompok bisa mengidentifikasi masalah sesuai dengan fenomena yang ditampilkan guru.

Sebagai refleksi di siklus II, guru lebih menekankan pada seluruh kelompok agar mengidentifikasi masalah sesuai dengan fenomena yang ditunjukkan dan tujuan pembelajaran serta memberikan pertanyaan bantuan yaitu: berdasarkan video pencemaran tanah yang kalian amati apa saja masalah yang dapat kalian temukan?". Pertanyaan yang diberikan oleh guru untuk mendorong peserta didik untuk meningkatkan kemampuan berfikirnya. Guru harus membimbing peserta didik dalam mengidentifikasi masalah sebanyak-banyaknya hal ini berguna agar peserta didik lebih memahami konsep melalui pertanyaan tentang masalah-masalah yang mereka identifikasi. Memberikan kesempatan siswa untuk mengidentifikasi dan menganalisa permasalahan yang mereka hadapi, merupakan teknik yang berguna dalam membangun pemahaman siswa agar lebih terbiasa untuk menemukan masalah (Wahab, 2018).

Pada tahap ketiga yaitu tahap pengumpulan data, kegiatan yang dilakukan guru yaitu: menjelaskan prosedur percobaan yang ada pada lembar kerja peserta didik (LPKD) dan membimbing peserta didik dalam mengumpulkan data hasil percobaan.

Pada aspek yang pertama yaitu menjelaskan prosedur percobaan yang ada pada LKPD, aktivitas guru sudah berjalan dengan baik dalam menjelaskan prosedur percobaan pengaruh konsentrasi detergen terhadap kelangsungan hidup ikan di siklus I. Prosedur percobaan di jelaskan tahap demi tahap sehingga membantu peserta didik dalam memahami prosedur percobaan yang akan dilakukan. Kategori baik yang telah didapatkan di siklus I dipertahankan disiklus II. Pada siklus II ini aktivitas guru dalam aspek menjelaskan prosedur percobaan yang ada di LKPD pun berkategori baik. Tahapan percobaan tetang pengaruh konsentrasi oli terhadap kelangsungan hidup cacing tanah juga dijelaskan guru berdasarkan tahap demi tahap sehingga peserta didik dapat lebih memahami prosedur percobaan yang akan dilakukan. Pada tahap persiapan pembelajaran, guru bertindak sebagai pengarah atau pengelola kegiatan dengan cara mengarahkan pengembangan rencana penyelidikan yang hendak dilakukan oleh peserta didik melalui memberikan penjelasan prosedur percobaan. Sehingga pembelajaran dengan menggunakan model discovery learning dapat berjalan efektif (Sani, 2015).

Pada aspek selanjutnya yaitu membimbing peserta didik dalam mengumpulkan data hasil percobaan. Pada aspek ini kegiatan pembelajaran belum berjalan dengan optimal. Hal ini dikarenakan guru hanya membimbing 6 dari 8 kelompok peserta didik untuk bekerjasama dalam mengumpulkan data hasil percobaan tentang pengaruh konsentrasi detergen terhadap kelangsungan hidup ikan di siklus I sehingga hanya 6 dari 8 kelompok yang bekerjasama dalam mengumpulkan data percobaan. Setelah dilakukan refleksi aktivitas guru di siklus II, guru membimbing dan mengawasi peserta didik membagi tugas tiap kelompoknya yang terdiri dari 4 orang untuk mengamati tanah denga penambahan oli 1 sendok, penambahan oli 2 sendok, tanpa tambahan oli dan 
mencatat hasil percobaan. Dengan pembagian tugas ini peserta didik memiliki tanggung jawab masing masing sehingga adanya kerjasama dalam mengumpulkan data percobaan yang dilakukan. Dengan pembagian tugas ini pun menyebabkan aktivitas peserta didik dalam bekerjasama untuk mengumpulkan data percobaan pun ikut menjadi optimal. Penerapan model discovery learning adalah untuk mengembangkan cara belajar peserta didik aktif dengan menemukan sendiri dan menyelidiki sendiri, maka akan diperoleh hasil yang tahan lama dalam ingatan serta tidak mudah dilupakan peserta didik (Hosnan, 2014).

Pada tahap keempat yaitu pengolahan data, kegiatan yang dilakukan guru yaitu: membimbing peserta didik mengolah data hasil percobaan yang diperoleh, dan membimbing peserta didik melakukan diskusi dan menjawab pertanyaan yang ada di LKPD.

Pada aspek pertama yaitu membimbing peserta didik mengolah data hasil percobaan yang diperoleh. Pada siklus I yang dilakukan guru di aspek ini belum terlaksana dengan optimal. $\mathrm{Hal}$ ini dikarenakan guru hanya membimbing 6 dari 8 kelompok peserta didik untuk mengolah data hasil percobaan tentang pengaruh konsentrasi detergen terhadap kelangsungan hidup ikan di siklus I sehingga hanya 6 kelompok yang dapat mengolah data hasil percobaan dengan benar. Sebagai refleksi di siklus II, guru membimbing seluruh kelompok (8 kelompok) dalam mengolah data sesuai dengan benar. Sehingga seluruh kelompok dapat mengolah data hasil percobaan dengan benar. Hal ini mengakibatkan aktivitas guru di siklus II telah terlaksana dengan optimal.

Pada aspek kedua yaitu membimbing peserta didik melakukan diskusi dan menjawab pertanyaan yang terdapat di LKPD. Kegiatan yang dilakukan guru pada siklus I dan siklus II sudah terlaksana dengan optimal (kriteria baik) karena guru sudah membimbing 8 kelompok peserta didik untuk melakukan diskusi dan menjawab pertanyaan yang ada di LKPD dan peserta didik juga sudah melakukan diskusi dan menjawab pertanyaan yang terdapat di LKPD. Hanya saja ketika mereka bingung maka mereka akan bertanya tentang kesulitan yang mereka amati. Dalam proses mengevaluasi kemajuan diri sendiri, peserta didik memiliki peranan khusus yaitu dengan ikut berpartisipasi dalam menjawab pertanyaan (Rusman, 2014).

Pada tahap kelima yaitu verification (pembuktian), Pada tahap ini kegiatan guru adalah membimbing peserta didik untuk melakukan verifikasi data. Kegiatan yang dilakukan guru pada siklus I dan II telah berjalan dengan optimal. Guru membimbing peserta didik untuk melakukan verifikasi dengan cara menginstruksikan kepada seluruh kelompok untuk membandingkan hasil dan jawaban percobaan dengan membaca literatur yang relavan, yaitu buku paket IPA yang dimiliki oleh peserta didik. Pada tahap verifikasi ini, peserta didik melakukan pemeriksaan secara cermat untuk membuktikan benar atau tidaknya hipotesis yang ditetapkan dengan temuan alternatif, dihubungkan dengan hasil data yang telah diolah (Permendikbud, 2014). Verifikasi bertujuan bertujuan agar proses belajar akan berjalan dengan baik dan kreatif untuk menemukan suatu konsep, teori, aturan atau pemahaman melalui contoh-contoh yang dijumpai dalam kehidupannya.

Pada tahap keenam yaitu Generalization (menarik kesimpulan), kegiatan guru adalah membimbing peserta didik untuk menarik kesimpulan tentang pencemaran lingkungan dari kegiatan 
percobaan pencemaran air dan pencemaran tanah yang telah dilakukan. Kegiatan yang dilakukan guru pada siklus I dan siklus II masih belum optimal. Karena guru hanya membimbing 6 dari 8 kelompok peserta didik dalam membimbing menarik kesimpulan untuk dipresentasikan, sehingga hanya 6 kelompok peserta didik saja yang bekerja sama dalam kelompok untuk menarik kesimpulan sesuai dengan tujuan percobaan.

Sebagai refleksi untuk proses pembelajaran berikutnya sebaiknya dalam tahap generalisasi guru lebih adil dalam membimbing seluruh kelompok untuk menarik kesimpulan sesuai dengan tujuan yang akan dicapai dalam proses pembelajaran. Ini dikarenakan proses generalisasi yang baik sangat berpengaruh terhadap pemahaman yang akan melekat pada ingata peserta didik. Tahap generalisasi dapat melahirkan sikap kemauan untuk mengubah pandangan, karena pada kegiatan ini ditetapkan suatu konsep tertentu yang merupakan hasil dari proses pembelajaran. Adanya proses induksi dari hal-hal khusus yang ditemukan dalam proses pembelajaran menuju pada hal-hal umum yang menjadi kesimpulan, maka akan terjadi proses konstruksi pengetahuan pada benak peserta didik yang memberikan penjelasan konsep sehingga memberikan pemahaman konseppada diri peserta didik (Widiadnyana dkk., 2014).

Kegiatan refleksi aktivitas guru dalam menerapkan model discovery learning materi pencemaran lingkungan memberikan perbaikan pemahaman konsep peserta didik.Berdasakan Gambar 1 diketahui bahwaterdaat perbaikan ratarata nilai dari siklus I ke siklus II. Pada siklus I, rata-rata pemahaman konsep peserta didik yaitu 74,7 dengan kategori baik dan pada siklus II meningkat hingga menjadi 82,8 dengan kategori sangat baik.
Persentase ketuntasan klasikal yang diperoleh peserta didik di siklus I adalah $70 \%$ dengan keterangan belum mencapai ketuntasan. Hal ini dikarenakan ketuntasan klasikal yang berlaku di SMPN 04 Kota Bengkulu adalah jika telah mencapai $\geq 85 \%$ peserta didik yang mencapai nilai KKM (75). Sedangkan disiklus II terjadi peningkatan persentase ketuntasan klasikal pada sub materi pencemaran tanah hingga menjadi $88 \%$ dengan keterangan telah mencapai ketuntasan klasikal yang berlaku.

Peningkatan pemahaman konsep terjadi karena dilakukannya perbaikan penerapan model discovery learning di siklus II dengan cara memperbaiki kekurangan yang ada di siklus I. Hal tersebut dikarenakan masing-masing tahap pada model discovery learning akan mempengaruhi pemahaman konsep yang akan diperoleh peserta didik, dimana 3 level pemahaman akan berkembang pada setiap tahapan model discovery learning. Kemampuan translasidankemampuan interpretasi berkembang saat peserta didik melakukan percobaan, terutama pada tahap pengumpulan datadan pengolahan data dalam model discovery learning. Selain itu kemampuan level ekstrapolasi berkembang saat peserta didik melakukan pengolahan data, dan generalisasi dalam model discovery learning(Fitriani, 2017 dan Huda, 2018).

Berdasarkan hasil penelitian secara keseluruhan, menunjukkan bahwa penerapan model discovery learning pada materi pencemaran lingkungan kelas $\mathrm{VII}_{4}$ SMPN 04 Kota Bengkulu ini dapat meningkatkan aktivitas guru dan aktivitas peserta didik. Dari peningkatan aktivitas tersebut terjadi peningkatan rata-rata pemahaman konsep peserta didik menjadi 82,8 dengan kriteria sangat baik. Peningkatan pemahaman ini terjadi karena pada prosesnya pembelajaran 
model discovery learning telah dilaksanakan dengan baik. Karakteristik dari discovery learning yang memfasilitasi melakukan proses sains mampu memberikan perbaikan kemampuan pemahaman. Peserta didik membangun pengetahuan dengan menemukan konsep sendiri melalui model discovery learning ini sehingga diperoleh hasil yang melekat lebih lama dalam ingatan peserta didik. Melalui percobaan penemuan, peserta didik lebih termotivasi untuk menemukan konsep dan membuat peserta didik lebih paham terhadap konsep yang dipelajari (Kurniasih, 2015).

Hasil yang didapatkan ini sesuai juga dengan penelitian yang telah dilakukan oleh Fitriani (2017) yang menyimpulkan bahwa penerapan model discovery learning dapat meningkatkan pemahaman konsep perserta didik kelas VIIF SMPN 11 Kota Bengkulu dari 55,6\% menjadi 76,7\%, Huda (2018) menyimpulkan bahwa penerapan Model discovery learning dapat meningkatkan pemahaman konsep peserta didik dengan persentase $59,26 \%$ berkategori tinggi, $33,33 \%$ berkategori sedang dan $7,41 \%$ berkategori rendah. Suhada (2018) yang menyimpulkan bahwa penerapan model discovery learning pada materi fotosintesis dapat meningkatkan hasil belajar peserta didik Kelas VIII SMPN 26 Seluma dengan ketuntasan klasikal menjadi $85 \%$.

Ucapan Terima Kasih, Kepada Ibu Mala Hartari, M.Pd selaku kepala sekolah SMPN 04 Kota Bengkulu, Ibu Rihaini, S.Pd selaku guru mata pelajaran biologi di SMPN 04 Kota Bengkulu dan seluruh peserta didik kelas $\mathrm{VII}_{4}$ SMPN 04 Kota Bengkulu tahun ajaran 2018-2019.

\section{PENUTUP}

\section{Simpulan}

Pembelajaran IPA Biologi pada materi pencemaran lingkungan dengan menerapkan model Discovery Learning dapat meningkatkan aktivitas guru dan aktivitas peserta didik kelas $\mathrm{VII}_{4}$ SMPN 04 Kota Bengkulu. Dari rerata skor aktivitas guru dari 23 di siklus I menjadi 25 dengan kriteria baik di siklus II.

Penerapan model discovery learning dalam proses pembelajaran IPA Biologi pada materi Pencemaran Lingkungan dapat meningkatkan rata-rat pemahaman konsep peserta didik Kelas $\mathrm{VII}_{4}$ SMPN 04 Kota Bengkulu dengan ratarata nilai 74,9 (baik) di siklus I menjadi 82,8 (sangat baik) di siklus II.

\section{Saran}

Jika ingin menggunakan model pembelajaran discovery learning diharapkan untuk dapat lebih memahami tiap tahapan dalam model tersebut, terutamapada tahapan membimbing peserta didik dalam mengidentifikasi masalah agar dapat menumbuhkan rasa ingin tahu peserta didik dalam mengidentifikasi sebanyak-banyaknya masalah yang relevan dengan materi yang akan dipelajari dan membimbing peserta didik dalam menarik kesimpulan untuk meningkatkan pemahaman konsep dari peserta didik menjadi lebih baik.

Pada penelitian selanjutnya jika ingin menggunakan model discovery learning ini agar meningkatkan kemampuan pemahaman konsep peserta didik sebaiknya lebih memperhatikan tahapan generalisasi terutama dalam memberikan penguatan konsep melalui contoh pencemaran yang konkret faktual dan konseptual agar didapatkan pemahaman yang lebih baik. 


\section{DAFTAR PUSTAKA}

Fitriani, Ulvia., Bhakti, K., \& Irwandi, A. (2017). Penerapan Model Discovery Learning Untuk Meningkatkan Pemahaman Konsep Biologi Peserta Didik SMP.Diklabio: Jurnal Pendidikan Biologi 1(1): $89-90$ (online) (https://ejournal.unib.ac.id/ index.php/jppb/article/download/31 52/1598). Di akses pada 18 September 2018

Hosnan. (2014). Pendekatan Saintifik dan Kontekstual Dalam Pembelajaran Abad 21. Bogor: Penerbit Ghalia Indonesia

Huda, \& Mochammad, K. (2018). Peningkatan Pemahaman konsep Peserta didik SMP Pada Submateri Asam Basa Garam dengan Penerapan Model Discovery Learning. Pensa eJurnal 6(2): 75-76 (online) (https://jurnalmahapeserta didik.unesa.ac.id/index.php/pensa/a rticle/download/23062/21130)

Diakses tanggal 1 September 2018

Kementerian Pendidikan dan Kebudayaan. (2016). Peringkat dan Capaian PISA Indonesia Mengalami Peningkatan. Jakarta: Kementerian Pendidikan dan Kebudayaan

Kurniasih, S. (2015). Pengembangan LKS Berbasis Model Discovery Learning Sebagai Upaya Peningkatan Pemahaman Konsep pada Materi Respirasi untuk Kelas VII SMPN 1 Pondok Kelapa. Skripsi tidak diterbitkan. Bengkulu: Program Studi Pendidikan Biologi FKIP Universitas Bengkulu

Permendikbud Nomor 58 Tahun 2014 tentang Kerangka Dasar dan Struktur Kurikulum SMP/MTs (salinan)
Roestiyah \& Suharto, Y. (1985). Proses Belajar Mengajar. Jakarta: Bina Aksara

Rusman. (2014). Model-model pembelajaran mengembangkan profesionalismeSekolah Menengah Pertama/Madrasah tsanawiyah. Jakarta: Kementerian Pendidikandan Kebudayaan.

Sani, \& Ridwan, A. (2013). Inovasi Pembelajaran. Jakarta: Bumi Aksara.

Sudijono, A. (2014). Pengantar Statistik Pendidikan. Jakarta : Rajawali Press.

Suhada, Rihwan., Irdam I., \& Kasrina. (2019). Penerapan Model Discovery Learning pada Materi Fotosintesis untuk Meningkatkan Hasil Belajar Peserta didik Kelas VIIIA SMPN 26 Seluma. Diklabio: Jurnal Pendidikan Biologi 3(1): 38-39 (online) (https://ejournal.unib.ac.id/index.ph p/ippb/article/view/7816/3956) Diakses pada 18 Juli 2019

Syah, M. (2005). Psikologi Pendidikan dengan Pendekatan Baru. Bandung: Remaja Rosdakarya

Wahab, N., \& Sundari, S. (2018). Model Discovery Learning Dalam Pembelajaran Biologi Metabolisme Untuk Meningkatkan Aktivitas Sains dan Hasil Belajar Siswa Kelas XII-IPA I Di SMA Negeri 4 Kota Ternate. Seminar Nasional Biologi Kepulauan (Vol. 1):

61 (http://ejournal.unkhair.ac.id/index. php/semnasbio/article/view/1040/7 74)Diakses pada 18 Juli 2019

Widyiadnyana, I. W., Sadja, I. W. \& Suastra, I. W. (2014). Pengaruh Model Discovery Learning Terhadap Pemahaman Konsep dan Sikap IImiah Siswa SMP. E-Journal Program 
Pascasarjana Universitas Pendidikan

Ganesha, 4(1): 8-11

(http://pasca.undiksha.ac.id/ejourna

l/index.php/jurnal ipa/article?view/

134) Diakses pada 6 maret 2019

Winarni, E. W. (2011). Penelitian

Pendidikan. Bengkulu : FKIP

Universitas Bengkulu 